\title{
Kidney Liposarcoma
}

National Cancer Institute

\section{Source}

National Cancer Institute. Kidney Liposarcoma. NCI Thesaurus. Code C6185.

A rare malignant adipose tissue neoplasm of the fat cells surrounding the kidney, usually

of the well-differentiated or myxoid type. It may be associated with tuberous sclerosis. 